14. Герман К.Э. Хронология и периодизация культуры сперрингс в Карелии // Тверской археологический сборник. Вып. 5. Тверь: Изд-во Тверская областная типография, 2002. С. 264-273.

15. Песонен П.Э. Поселения культуры сперрингс // Поселения древней Карелии. Петрозаводск: Изд-во КНЦ РАН, 1988. С. 41-49.

16. Лобанова Н.В. Проблемы этнокультурной истории эпохи неолита Карелии // Проблемы этнокультурной истории населения Карелии (мезолит - Средневековье). Петрозаводск: Изд-во КНЦ РАН, 2006. C. 112-137.

17. Герман К.Э. Ранняя гребенчатая керамика в бассейне Онежского озера // Тверской археологический сборник. Вып. 3. Тверь: Изд-во Тверская областная типография, 1998. С. 266-272.

18. Иванищев А.М., Иванищева М.В. Тудозеро поселение позднего мезолита - раннего неолита в Южном Прионежье // Тверской археологический сборник. Вып. 4. Тверь: Изд-во Тверская областная типография, 2000. С. 284-295.

19. Норквист К. Неолитическая керамика в Финлядии: терминология, хронология, распространение // Тверской археологический сборник. Т. 1, вып. 10. Тверь: ООО «Издательство «Триада», 2015. С. 249265.

20. Нордквист К., Мёккёнен Т. Новые данные по археологической хронологии Северо-Запада России: AMS-датировки неолита-энеолита Карелии // Тверской археологический сборник. Вып. 11. Тверь: ООО «Издательство «Триада», 2018. С. 39-68.

21. Мельников И.В., Герман К.Э. Древние поселения южного Заонежья (мезолит - энеолит). Петрозаводск: Изд-во КНЦ РАН, 2013. 408 с.

Работа выполнена из средств федерального бюджета на выполнение государственного задания КарНЦ РАН.

\title{
THE POTTERY OF THE FINAL PHASE OF SPERRINGS CULTURE
}

(C) 2019

German Konstantin Enrikovich, candidate of historical sciences, senior researcher of Archaeology Sector Institute of Linguistics, Literature and History of Karelian Research Centre of Russian Academy of Sciences (Petrozavodsk, Russian Federation)

Abstract. The paper is devoted to the poorly studied final period of the existence of Early Neolithic Sperrings culture. There are few settlements of this period - Voynavolok XX, Sandermoha II, Pindushi and Sulgu Va, they are presented in mixed complexes with proscenium stone tools and the absence of radiocarbon dates. No transitional complexes between the developed and final stages of the sperrings culture have been identified. The ceramics of the final stage has a number of differences from the «classic» sperrings. This lack of ornamentation imprints fish vertebra and the retreating lines. At the same time there are imprints of the corded stamps and oval (rhomboid) pits, roundconical pits marked on the main pattern - characteristic features of the advanced stage of the sperrings culture. The main ornament is horizontal zones inclined right and left with a short-cut or corded stamps, comb stamp or oval (rhomboid) pits that form a vertical zigzag lines coated on top of horizontal belts of round-conical pits, sometimes arranged in a staggered manner. Such a change of pottery decoration hasn't been noted by experts studying early Neolithic ceramics of Karelia due to a small number of vessels and their presence in mixed complexes. Therefore, the development of the sperrings culture is likely to have been continued in some areas of South Karelia, but it is poorly recorded due to the refusal of the ancient population to use a fish vertebra as ornamentation as well as the transition to comb stamps.

Keywords: Karelia; Onega lake; Syamozero; North-Western Ladoga area; Karelian Isthmus; Early Neolithic; sperrings culture; final stage of archaeological culture; chronology; radiocarbon dating; Tudozero V settlement; sperrings ceramics; comb ceramics; vertebral ornamentation; retreating-drawn ornamentation: comb stamp; rope impressions.

УДК 902.01

DOI 10.24411/2309-4370-2019-12209

Статья поступила в редакцию 27.02.2019

\section{ПЕРИОДИЗАЦИЯ И ХРОНОЛОГИЯ ПРИКАСПИЙСКОЙ КУЛЬТУРЫ}

(C) 2019

Дога Наталья Сергеевна, аспирант кафедры отечественной истории и археологии

Самарский государственный соииально-педагогический университет (2. Самара, Российская Федераиия)

Аннотациия. Долгое время вопросы периодизации и хронологии прикаспийской культуры оставались дискуссионными. Одни исследователи относили культуру к периоду неолита, а другие к энеолиту. В работе представляются все имеющиеся точки зрения относительно периодизации прикаспийской культуры. Дается ее краткая характеристика. Так же, в статье рассматриваются критерии выделения эпохи энеолита и приводятся аргументы в пользу энеолитического характера прикаспийской культуры. Обосновывается факт отсутствия производящего хозяйства у неолитического населения региона и наличие его у носителей прикаспийской культуры. О принадлежности культуры к эпохе энеолита говорят следующие факторы: изменение техники обработки каменных орудий, орнаментации посуды; наличие домашних животных. Рассматривается концепция существования в Нижнем Поволжье периода нео-энеолита и возможность отнесения прикаспийской культуры к нему. Анализируются концепции исследователей относительно хронологического соотношения прикаспийской и хвалынской культур; обосновывается вывод о хронологическом приоритете прикаспийской культуры. Даются все, имеющиеся на сегодняшний день, радиоуглеродные значения по материалам культуры и аргументируется вывод о том, что прикаспийская культура представляет собой ранний этап энеолита Нижнего Поволжья. 
Ключевые слова: Нижнее Поволжье; Северный Прикаспий; степное Поволжье; прикаспийская культура; орловская культура; хвалынская культура; неолит; энеолит; нео-энеолит; керамика; каменный инвентарь; радиоуглеродное датирование; хронологический интервал; периодизация; хронология; стратиграфия.

В 70-е годы XX века на территории Северного Прикаспия А.Н. Мелентьев обнаружил керамику с плоским дном и «воротничковым» оформлением венчика. Посуда была орнаментирована прочерченными зигзагами и рядами шагающей гребенки. Каменный инвентарь, залегающий вместе с данной керамикой, представлен скребками и наконечниками стрел на крупных кварцитовых пластинах. На основании этих материалов исследователь выделил прикаспийскую культуру и отнес ее к периоду позднего неолита $[1$, с. 12]. В дальнейшем, исследования в этом направлении были продолжены. На сегодняшний день известно почти 40 пунктов с материалами прикаспийской культуры. На девяти из них сохранился культурный слой, который подвергался исследованиям. Работы И.Б. Васильева, П.П. Барынкина, А.И. Юдина, В.А. Лопатина и других специалистов, позволили расширить ареал культуры до степного Заволжья и Волго-Уральского междуречья и поставить вопрос об уточнении ее периодизации и хронологии. И.Б. Васильев отнес прикаспийскую культуру к первому этапу энеолита [2, с. 63]. Автор указывал на смену микролитической кремневой индустрии неолитического времени макролитичными кварцитовыми орудиями. Изменения фиксировались и в орнаментации посуды: произошла смена накольчатой и накольчато-прочерченной традиции на гребенчатопрочерченную [3, с. 71]. Эту точку зрения поддержала Н.Л. Моргунова, говоря о том, что прикаспийская культура представляет собой ранний этап энеолита степного Поволжья. [4, с. 185]. А.И. Юдин выделяет для территории степного Поволжья период неоэнеолита, и относит прикаспийскую культуру к этому этапу. [5, с. 25]. В.В. Ставицкий, отрицая существование нео-энеолитического этапа в Нижнем Поволжье, связывает период энеолитизации региона с населением хвалынской культуры, а прикаспийскую считает неолитической [6, с. 32] Таким образом, формируется три точки зрения, относительно периодизации прикаспийской культуры. Одни исследователи относят ее к неолиту, другие к энеолиту, а третьи к переходному этапу нео-энеолита.

Необходимым представляется определение критериев, по которым можно отнести ту или иную культуру к эпохе энеолита, и соответствие или несоответствие прикаспийской культуры этим критериям. Н.Я. Мерперт под энеолитом понимает период регулярного распространения металлических орудий труда. Автор утверждает, что единственным критерием перехода от одной эпохи к другой является смена материалов орудий. А изменение, например, форм экономики, признак не устойчивый [7, с. 20]. По мнению исследователя энеолит ограничивается южной территорией, на которой господствует земледельческая форма хозяйства; но там производящее хозяйство зарождается еще в неолите, и проследить четких изменений по этому признаку невозможно [8, c. 3]. На памятниках прикаспийской культуры металлических изделий не обнаружено, но их нет и на памятниках всей мариупольской культурно-исторической области, за исключением единичных предметов в Никольском могильнике. Поэтому многие исследователи придерживаются комплексного подхода, который оказался более приемлемым для определения эпохи энеолита. М.Е. Фосс считала определяющим не только наличие металлических изделий, но и появление новых приемов обработки кремня [9, c. 42]. Каменный инвентарь прикаспийской культуры представляет собой результат сочетания макро и микро техники, а так же наличие усиленного отжима, что показывает значительные различия в технике обработки камня с предшествующей неолитической орловской культурой. Что касается керамической посуды, то и здесь прослеживаются отличия в технике нанесения орнамента. Накольчатая традиция орловцев не имеет своего продолжения в керамике прикаспийцев, а сменяется гребенчатой техникой. Для прикаспийской керамики характерны «воротничковый» венчик и разнообразие меандровых узоров, заполненных рядами шагающей гребенки. Л.Я. Крижевская в определении термина «энеолит» основополагающим признаком, наравне с остатками металла, считала наличие костей доместицированных животных $[10$, с. 5]. В этой связи необходимо отметить, что исследования последних лет доказали факт отсутствия доместицированных животных у неолитического населения Нижнего Поволжья. На эпонимной Варфоломеевской стоянке степного Поволжья костей домашних животных не обнаружено [11, c. 26]. Исследование нового неолитического памятника региона - стоянки Алгай, показало наличие костей только диких видов [12, с. 20]. На территории Северного Прикаспия останки домашних животных на неолитических памятниках так же не были обнаружены. На АMC в г. Уппсала была продатированна кость овцы с неолитической стоянки Тентексор I. Полученная дата 3555 лет ВС оказалась значительно моложе основного неолитического комплекса памятника $[13$, с. 9]. На новой для региона неолитической стоянке Байбек тоже были зафиксированы кости только диких животных [11]. Единственным домашним животным Нижнего Поволжья в эпоху неолита была собака. Предположение о скотоводческой направленности племен прикаспийской культуры высказал еще А.Н. Мелентьев [14, с. 7], а после исследования прикаспийского слоя памятника Орошаемое факт наличия у прикаспийского населения доместицированных животных, стал бесспорным [15, с. 237 ; 16 , с. $134 ; 17$, с. 189$]$ ].

Иначе говоря, по ряду признаков: изменение техники обработки каменных орудий, орнаментации посуды и появлению домашних животных прикаспийскую культуру можно отнести к периоду энеолита.

Что касается концепции А.И. Юдина о существовании на территории Нижнего Поволжья переходного нео-энеолитического этапа $[18$, с. 28$]$, то ситуация представляется неоднозначной. Модель периода неоэнеолита для территории Волго-Донья предлагал еще Д.Я. Телегин. Теория строилась на факте сосуществовании пришлой энеолитической трипольской культуры с местным неолитическим населением [19, c. 106-121]. Эту точку зрения поддерживал А.Т. Синюк, выделяя на Среднем Дону период пережиточного неолита, и предлагая перенести эти реалии на всю зону восточно-европейской лесостепи [20, с. 195 206]. На территории Нижнего Поволжья И.Б. Васи- 
льев и А.А. Выборнов фиксировали существование памятников с керамикой, которая сочетала в себе наличие накольчатого орнамента и «воротничкового» венчика. Первый признак присущ неолиту, а второй - раннему энеолиту. При наличии различных экологических ниш на данной территории, а в них незначительной плотности населения в конце неолита - начале энеолита, допускалось их сосуществование $[21$, с. 12]. Даты по керамике прикаспийской культуры стоянок Северного Прикаспия укладываются в интервал от второй четверти до конца V тыс. до н.э. [22, с. 56]. Из этого А.И. Юдин делает вывод, что поздненеолитическое и раннеэнеолитическое население Нижнего Поволжья сосуществовало довольно значительное время [18, с. 28].

Концепцию неолита-энеолита в Волго-Донских степях развивает и И.Н. Наумов. Автор выделяет финально-неолитический этап, и относит к нему артефакты Орловки и слоя 2А Варфоломеевской стоянки, а так же памятник Тентексор I. В подтверждение этого, исследователь приводит следующие аргументы: сокращение количества орудий, выполненных в пластинчатой технике; появление двусторонне обработанных орудий; смена прочерченного орнамента на отступающе-накольчатый; профилировка сосудов; появление наплывов на внутренней стороне венчика. А следующий этап энеолита, по мнению автора, представляют собой материалы верхнего горизонта Варфоломеевской стоянки. И.Н. Наумов отмечает преобладание кварцита в качестве сырья для орудий труда, вытеснение пластинчатых орудий двусторонне обработанным, общая макролитизация орудий, а также увеличением доли керамики с примесью толчёной ракушки в глиняном тесте. Так же, наблюдается распространение гребенчатой орнаментации керамики и сосудов с «воротничковыми» венчиками. Анализируя существующие радиоуглеродные даты, исследователь приходит к выводу, что энеолитическое население в Нижнем Поволжье появляется в конце V - на рубеже V-IV тыс. до н.э. С этого этапа и до середины IV тыс. до н.э., во время, которое можно именовать переходным неолитоэнеолитическим периодом, в регионе сосуществовали разнокультурные пережиточно неолитические и энеолитические памятники [23, с. 17]. Опираясь на радиоуглеродные датировки П.М. Кольцов так же относит стоянку Тентексор I к пережиточному неолиту [24, с. 130]. По разным материалам памятника было получено несколько дат, которые фиксируют середину V тыс. до н.э. [25, с. 258]. Радиоуглеродный возраст материалов прикаспийской культуры определяется интервалом 5840-5056 ВС (табл. 1). Необходимо отметить, что ранние даты получены по материалам Северного Прикаспия, а поздние - степного Поволжья. Так для стоянок Северного Прикаспия Курпеже - Молла и Буровая 41 были получены даты 5000 ВС и 5800 ВС соответственно (табл. 1: 14). На этом основании А.А. Выборнов выдвигает предположение о частичном сосуществование памятников прикаспийского типа и неолитического населения с накольчатой посудой на территории Северного Прикаспия во второй четверти V тысячелетии до н.э. [26, с. 60]. Кроме того, П.М. Кольцов фиксирует наличие «воротничка», характерного для прикаспийской культуры, на неолитической накольчато-прочерченной керамики стоянки Джангар. Автор считает «воротничок» местной традицией, но, к сожалению, не приводит аргументов в пользу этой версии [27, с. 321].

В степном Поволжья ситуация складывается несколько иначе. На основании совместного залегания прикаспийской и орловской керамики на стоянке Варфоломеевская, А.И. Юдин делает вывод о сосуществовании неолитической орловской и прикаспийской культур [28, с. 89]. Датировки, полученные по прикаспийским материалам этого региона укладываются в интервал 4700-5000 ВС (табл. 1: 5-8). Однако, имеющиеся на сегодняшний день, самые поздние даты орловской культуры не превышают хроноинтервала 5625-5265 ВС [29, с. 64]. Что касается совместного залегания, то необходимо учитывать, что на Варфоломеевской стоянке есть несколько жилищ, которые прорезают слой [30, с. 20]. Вполне допустимо, что в таких условиях, материалы из разных культурных горизонтов могли смешаться.

Таким образом, возможно допустить сосуществование в Северном Прикаспии памятников неолитического тентексорского типа и энеолитического прикаспийского, но в степном Поволжье такая ситуация не прослеживается.

Радиоуглеродные даты материалов североприкаспийских стоянок прикаспийской культуры Курпеже-Молла и Буровая 41 выглядят несколько древнее значений материалов памятников степного Поволжья Кумыска и Орошаемое. Разница составляет порядка трехсот лет. В этой связи логичным становится вопрос о валидности четырех дат по керамике стоянок Курпеже-Молла и Буровая 41. Как уже было отмечено выше, ареал распространения прикаспийской культуры доходит до северных границ степной зоны Заволжья. Здесь прикаспийцы граничат с носителями самарской культуры. Первый этап культуры представлен керамикой съезжинского типа. Это плоскодонная посуда с массивными «воротничками», преобладанием прочерченных узоров в виде многорядных и волнистых линий и меандровых фигур, которые заполнены рядами шагающей гребенки [22; 24]. По форме «воротничка», меандровым композициям и плоскодонности данная керамика схожа с прикаспийской. Даты, полученные по съезжинской керамике, соответствуют интервалу 5730-5470 ВС [22, c. 55, табл. 1], что хорошо соотносится с датами прикаспийской стоянки Буровая 41.

Сравнительный анализ материалов прикаспийской, азово-днепровской и нижнедонской культур показал наличие некоторых аналогий. Посуда азоводнепровской культуры имеет примесь толченой раковины в тесте и орнаментирована оттисками гребенчатого штампа, позднее появляется керамика с «воротничковым» оформлением венчика [31, с. 25]. Нижнедонская керамика имеет аналогичную орнаментацию. На втором этапе появляется «воротничок» [32, с. 37]. Что касается каменного инвентаря, то для вышеперечисленных культур характерна техника скалывания крупных пластин. Этап 1б азоводнепровской культуры и второй период нижнедонской культуры датируется 5800 ВС [31, с. 95-97]. Это хорошо коррелируется с датами аналогичной посуды памятника Буровая 41. Второй этап азоводнепровской культуры имеет возраст 5300 ВС, а это совпадает со значениями по сходной керамике со стоянки Курпеже-Молла. Кроме того, на памятниках вышеупомянутых культур были обнаружены кости домашних животных [31, с. 53]. 
Дога Н.С.

Таблица 1 - Радиоуглеродные значения прикаспийской культуры

\begin{tabular}{|c|l|c|c|c|c|}
\hline № & \multicolumn{1}{|c|}{ Памятник } & $\begin{array}{c}\text { Радиоуглеродное } \\
\text { значение (ВР) }\end{array}$ & $\begin{array}{c}\text { Калиброванное } \\
\text { значение (BC) }\end{array}$ & $\begin{array}{c}\text { Лабораторный } \\
\text { индекс }\end{array}$ & Материал \\
\hline 1 & Курпеже-Молла & $6050 \pm 80$ & $5050-4770$ & Ki-14831 & керамика \\
\hline 2 & Курпеже-Молла & $6020 \pm 80$ & $5000-4710$ & Ki-14832 & керамика \\
\hline 3 & Буровая 41 & $6880 \pm 80$ & $5840-5630$ & Ki-14616 & керамика \\
\hline 4 & Буровая 41 & $6790 \pm 80$ & $5740-5530$ & Ki-14618 & керамика \\
\hline 5 & Кумыска & $5870 \pm 70$ & $4810-4540$ & Ki-16271 & керамика \\
\hline 6 & Орошаемое & $5806 \pm 26$ & $4724-4557$ & UGAMS-23059 & кость овцы \\
\hline 7 & Орошаемое & $5934 \pm 100$ & $5060-4547$ & SPb-2091 & кость \\
\hline 8 & Орошаемое & $5890 \pm 120$ & $5056-4462$ & $\mathrm{SPb}-1729$ & керамика \\
\hline
\end{tabular}

Таким образом, даты североприкаспийских стоянок прикаспийской культуры представляются валидными, а такой разрыв в датировках может объясняться существованием двух этапов внутри прикаспийской культуры. Это прослеживается по керамике и каменному инвентарю. Наиболее ранним признаком для прикаспийской посуды можно считать наличие валют и сочетание гребенчатого штампа с прочерками. Этой посуде соответствует каменный инвентарь, выполненный преимущественно из кварцита. На более поздней керамике стоянки Орошаемое, становится менее выразительной. Кроме того, значительно увеличивается процент кремневых орудий. Вполне приемлемой является модель миграции прикаспийского населения с территорий Северного Прикаспия в степное Поволжье.

Бесспорной энеолитической культурой Нижнего Поволжья считается хвалынская культура. Что касается хронологического соотношения прикаспийской и хвалынской культур, то ситуация представляется не однозначной. И.Б. Васильев считал, что хвалынская культура сформировалась на основе прикаспийской и самарской культур [33, с. 72], и вследствие этого, прикаспийская культура имеет хронологический приоритет. П.П. Барынкин, считая прикаспийцев региональным типом самарской культуры, говорил о сосуществовании этого населения по всему волжскому региону их распространения [34, с. 12$]$. Н.Л. Моргунова, основываясь на серии радиоуглеродных дат, делает вывод о более позднем положении хвалынской культуры относительно прикаспийской и самарской. Однако, исследователь допускает их сосуществование в период формирования хвалынской культуры [4, с. 187]. А.А. Выборнов, принимая во внимание радиоуглеродные даты по прикаспийским и хвалынским памятникам Северного Прикаспия, пишет о более раннем положении прикаспийской культуры, однако указывая на тот факт, что позднеприкаспийские и хвалынские датировки совпадают [35, с. 193]. А.И. Юдин делает свои выводы, по данному вопросу, основываясь в первую оче- редь, на стратиграфии. Согласно стратиграфическим данным Варфоломеевской стоянки, прикаспийская и позднеорловская керамика предшествуют хвалынской [30, с. 47]. Подтверждением этого служат данные памятника Кумыска, где прикаспийская керамика залегает ниже хвалынской [5, с. 12]. Радиоуглеродные датировки керамики североприкаспийских памятников Буровая 41 и Курпеже-Молла, укладываются в промежуток 5000-5800 ВС. Датировки прикаспийских материалов степного Поволжья представлены одной датой со стоянки Кумыска и четырьмя датами материалов стоянки Орошаемое. Полученные значения соответствуют первой четверти $\mathrm{V}$ тыс. до н.э. Для поселенческих материалов хвалынской культуры Северного Прикаспия можно признать наиболее достоверными хронологические рамки 4800-4400 ВС (табл. 2). Дата по углю - 5290 ВС с еще одной хвалынской стоянки Комбак-те выбивается из ряда остальных дат, но повторный анализ коллекции показал наличие материалов прикаспийской культуры, к которым очевидно и относится эта дата, хорошо согласующаяся с датами памятника Курпеже-Молла [36, с. 22]. Что касается степного Поволжья, то по костям кулана из стратифицированного хвалынского слоя поселения Орошаемое получена дата 4725 ВС (табл. 2: 7), что вполне укладывается в период бытования хвалынской культуры. Вероятно, памятники хвалынской культуры появляются в Северном Прикаспии раньше чем в степном Поволжье. Исходя из представленных радиоуглеродных значений, можно сделать вывод о более раннем хронологическом положении прикаспийцев, относительно хвалынцев. Кроме того, тезис А.И. Юдина о хронологическом приоритете прикаспийцев на основании стратиграфии памятника Кумыска подтвердился на примере Орошаемого. Слой с материалами прикаспийской культуры залегает ниже хвалынского [17, c. 185]. Их разделяет мощная стерильная прослойка. По данным геохимии эта прослойка образовалась в течение 100 лет вследствие сильной аридизации.

Таблица 2 - Радиоуглеродные значения хвалынской культуры

\begin{tabular}{r|l|c|c|c|c|}
\hline № & \multicolumn{1}{|c|}{ Памятник } & $\begin{array}{c}\text { Радиоуглеродное } \\
\text { значение (ВР) }\end{array}$ & $\begin{array}{c}\text { Калиброванное } \\
\text { значение (BC) }\end{array}$ & $\begin{array}{c}\text { Лабораторный ин- } \\
\text { декс }\end{array}$ & Материал \\
\hline 1 & Кара-Худук & $5980 \pm 90$ & $4850-4490$ & Ki-14907 & керамика \\
\hline 2 & Кара-Худук & $5950 \pm 80$ & $5048-4654$ & Ki-14912 & керамика \\
\hline 3 & Кара-Худук & $5820 \pm 80$ & $5040-4680$ & Ki-14911 & керамика \\
\hline 4 & Кара-Худук & $5870 \pm 70$ & $4900-4548$ & $\mathrm{SPb}-2339$ & кости кулана \\
\hline 5 & Кара-Худук & $5854 \pm 60$ & $4847-4547$ & $\mathrm{SPb}-2338$ & кости овцы \\
\hline 6 & Кара-Худук & $5900 \pm 100$ & $5000-4530$ & $\mathrm{SPb}-2365$ & кости КРС \\
\hline 7 & Орошаемое & $5667 \pm 100$ & $4725-4336$ & $\mathrm{SPb}-1474$ & кости \\
\hline 8 & Каиршак VI & $5920 \pm 80$ & $4810-4450$ & Ki-14909 & керамика \\
\hline 9 & Каиршак VI & $5780 \pm 80$ & $4802-4457$ & Ki-14910 & керамика \\
\hline 10 & Каиршак VI & $5664 \pm 80$ & $4687-4356$ & AAR-26175 & нагар \\
\hline 11 & Комбакте & $5626 \pm 51$ & $4550-4350$ & AAR-22804 & нагар \\
\hline 12 & Каиршак VI & $5460 \pm 70$ & $4456-4224$ & SPb-2340 & кости овцы \\
\hline \hline
\end{tabular}


Таким образом, можно сделать вывод о том, что прикаспийская культура относится к периоду раннего энеолита. С определенными видоизменениями она просуществовала около тысячи лет, укладываясь в интервал 5840-4800 лет ВС.

\section{Список литературы:}

1. Мелентьев А.Н. Памятники неолита Сев. Прикаспия (памятники прикаспийского типа) // Проблемы археологии Поволжья и Приуралья. Куйбышев, 1976. С. 13-14.

2. Васильев И.Б. Энеолит Поволжья (степь и лесостепь). Куйбышев: КГПИ, 1981. 129 с.

3. Барынкин П.П., Васильев И.Б. Новые энеолитические памятники Северного Прикаспия // Археологические памятники на Европейской территории СССР. Воронеж, 1985. С. 60-65.

4. Моргунова Н.Л. К вопросу о синхронизации и культурных связях культур энеолита и раннего бронзового века степного-лесостепного Поволжья и Приуралья с культурами лесной зоны Волго-Камья // 40 лет Средневолжской археологической экспедиции: Краеведческие записки. Вып. XV. 2010. С. 184-193.

5. Юдин А.И. Поселение Кумыска и энеолит степного Поволжья. Саратов: Научная книга, 2012. 212 с.

6. Ставицкий В.В. К вопросу о выделении неоэнеолитической эпохи в Поволжье // Проблемы периодизации и хронологии в археологии эпохи раннего металла Восточной Европы. СПб.: Скифия-принт, 2013. C. 31-33.

7. Мерперт Н.Я. К вопросу о термине «энеолит» и его критериях // Эпоха бронзы Волго-Уральской лесостепи. Воронеж: Изд-во Воронеж. ун-та, 1981. C. 4-21.

8. Мерперт Н.Я. Проблемы энеолита степи и лесостепи Восточной Европы // Энеолит Восточной Европы. Куйбышев, 1980. С. 3-5.

9. Фосс М.Е. О терминах «неолит», «бронза», «культура» // Краткие сообщения Института истории материальной культуры. Вып. 29. М.-Л., 1949. С. 33-47.

10. Крижевская Л.Я. Неолит и эпоха ранней бронзы на Южном Урале: автореф. дис. ... д-ра ист. наук. Новосибирск, 1979. 49 с.

11. Гасилин В.В., К Косинцев П.А., Саблин М.В. Фауна неолитической стоянки Варфоломеевская в степном Поволжье // Фауна и флора Северной Евразии в позднем кайнозое. Екатеринбург-Челябинск: Рифей, 2008. С. 25-100.

12. Барацков А.В. Культурно-хронологическое соотношение неолитических памятников степного Поволжья: автореф. ... дис. канд. ист. наук. Ижевск, $2017.82 \mathrm{c}$.

13. Выборнов А.А., Ойнонен М., Дога Н.С., Кулькова М.А., Попов А.С. О хронологическом аспекте происхождения производящего хозяйства в Нижнем Поволжье // Вестник ВолГУ. Сер. 4. 2016. Т. 21, № 3. С. 6-13.

14. Мелентьев А.Н. О возникновении скотоводства в евразийских степях // Проблемы эпохи энеолита степной и лесостепной полосы Восточной Европы: тез. докл. Оренбург, 1980. С. 7-8.

15. Выборнов А.А., Юдин А.И., Васильева И.Н., Косинцев П.А., Кулькова М.А., Гослар Т., Дога Н.С. Новые материалы неолита Нижнего Поволжья // Известия Самарского научного центра РАН. 2015. T. 17, № 3. C. 235-241.

16. Выборнов А.А., Юдин А.И., Васильева И.Н., Косинцев П.А., Кулькова М.А., Дога Н.С., Попов А.С. Исследования поселения Орошаемое в Нижнем Поволжье // Известия Самарского научного центра PAH. 2016. T. 18, № 3. C. 140-145.
17. Выборнов А.А., Юдин А.И., Васильева И.Н., Косинцев П.А., Дога Н.С., Попов А.С. Новые результаты исследований поселения Орошаемое в Нижнем Поволжье // Известия Самарского научного центра РАН. 2017. Т. 19, № 3. С. 185-190.

18. Юдин А.И. Периодизация и хронология энеолита степного Поволжья // Проблемы периодизации и хронологии в археологии эпохи раннего металла Восточной Европы. СПб.: Скифия-принт, 2013. С. 26-30.

19. Телегин Д.Я. О хронологии и периодизации культур неолита и медного века юго-запада Восточной Европы. Понятия о нео-энеолитическом времени региона // Проблемы хронологии и этнокультурных взаимодействий в неолите Евразии. СПб.: Институт истории материальной культуры РАН, 2004. С. 106-121.

20. Синюк А.Т. Проблемы хронологии неолита лесостепного Подонья // Проблемы хронологии и этнокультурных взаимодействий в неолите Евразии. СПб., 2004. С. 195-206.

21. Васильев И.Б., Выборнов А.А. Неолит Поволжья. Куйбышев: КГПИ, 1988. 112 с.

22. Моргунова Н.Л. Энеолит Волжско-Уральского междуречья. Оренбург: ОГПУ, 2011. 234 с.

23. Наумов И.Н. Неолит Поволжско-Донских степей (проблемы хронологии, периодизации и культурно-хозяйственного развития): автореф. дис. ... канд. ист. наук. Воронеж, 2004. 24 с.

24. Кольцов П.М. Поселение Джангар. М.: Изд-во «Новый Хронограф», 2004. 156 с.

25. Барацков А.В., Выборнов А.А., Кулькова М.А. Проблемы абсолютной хронологии неолита Северного Прикаспия // Известия Самарского научного центра РАН. 2012. Т. 14, № 3. С. 254-260.

26. Выборнов А.А. Неолит Волго-Камья. Самара: СГПУ, 2008. 490 с.

27. Кольцов П.М. Мезолит и неолит Северо-Западного Прикаспия. М.: ГЖО «Воскресенье», 2005. 432 с.

28. Юдин А.И. Орловская культура и истоки формирования степного энеолита Заволжья // Проблемы древней истории Северного Прикаспия. Самара, 1998. С. 83-105.

29. Выборнов А.А., Юдин А.И., Кулькова М.А., Гослар Т., Посснерт Г., Филиппсен Б. Радиоуглеродные данные для хронологии неолита Нижнего Поволжья // Радиоуглеродная хронология эпохи неолита Восточной Европы VII-III тысячелетия до н.э. Смоленск: Свиток, 2016. С. 62-73.

30. Юдин А.И. Варфоломеевская стоянка и неолит степного Поволжья. Саратов: Саратовский университет, 2004. 201 с.

31. Котова Н.С. Неолитизация Украины. Луганск: Шлях, 2002. 267 с.

32. Котова Н.С. Древнейшая керамика Украины. Киев-Харьков: Майдан, 2015. 153 с.

33. Васильев И.Б. Хвалынская энеолитическая культура Волго-Уральской степи и лесостепи (некоторые итоги исследования) // Вопросы археологии Поволжья. Вып. 3. Самара, 2003. С. 61-99.

34. Барынкин П.П. Энеолит и ранняя бронза Северного Прикаспия: автореф. дис. ... канд. ист. наук. М., 1992. 26 c.

35. Выборнов А.А., Ковалюх Н.Н., Скрипкин В.В. О корректировке абсолютной хронологии неолита и энеолита Северного Прикаспия // Труды II (XVIII) всерос. археологического съезда в Суздале. Т. 1. М., 2008. С. 191-193.

36. Выборнов А.А., Дога Н.С., Попов А.С., Филиппсен Б. Материалы стоянки Комбак-тэ в Северном Прикаспии // Проблемы археологии Нижнего Поволжья: мат-лы V междунар. Нижневолжской археологической конф. Элиста, 2016. С. 20-24. 


\section{PERIODIZATION AND CHRONOLOGY OF CASPIAN CULTURE}

(C) 2019

Doga Natalia Sergeevna, postgraduate student of Domestic History and Archeology Department Samara State University of Social Sciences and Education (Samara, Russian Federation)

Abstract. For a long time the issues of periodization and chronology of the Caspian culture remained controversial. Some researchers attributed the culture to the Neolithic period, while others - to the Eneolithic. The paper presents all the available views on the periodization of the Caspian culture. Its brief characteristic is given. The paper also considers criteria for the allocation of the Eneolithic era and provides arguments in favor of the Eneolithic nature of the Caspian culture. The author substantiates the fact that the producing economy of the Neolithic population was absent in the region while it was present in the Caspian culture. The following factors say that the culture belonged to the era of the Eneolithic: changes in the technique of processing stone tools, ornamentation of dishes; the presence of pets. The author considers the concept of the neo-Eneolithic period existence in the Lower Volga region and the possibility of attributing the Caspian culture to it. The author analyzes researchers' point of view on the chronological relationship of the Caspian and the Khvalyn cultures; the conclusion is made about the chronological priority of the Caspian culture over the Khvalyn culture. All available radiocarbon values on materials of culture are presented and the author concludes that the Caspian culture represents an early stage of the Eneolithic of the Lower Volga region.

Keywords: Lower Volga region; Northern Caspian region; steppe Volga region; Caspian culture; Orel culture; Khvalyn culture; Neolithic; Eneolithic; neo-Eneolithic; ceramics; stone tools; radiocarbon Dating; chronological interval; periodization; chronology; stratigraphy.

УДК 902.01

DOI 10.24411/2309-4370-2019-12210

Статья поступила в редакцию 25.02.2019

\section{АНАЛИЗ ВЕЩЕВОГО КОМПЛЕКСА И НОВЫЕ РАДИОУГЛЕРОДНЫЕ ДАТИРОВКИ РАННЕНЕОЛИТИЧЕСКОГО ГОРОДИЩА АМНЯ I}

Дубовцева Екатерина Николаевна, научный сотрудник сектора археологии каменного века Институт истории и археологии УрО РАН (2. Екатеринбург, Российская Федерация)

Косинская Любовь Львовна, кандидат исторических наук, старший научный сотрудник центра археологических исследований, доцент кафедры археологии и этнологии Уральский федеральный университет им. первого президента России Б.Н. Ельциина (2. Екатеринбург, Российская Федераџия)

Пиецонка Хенни, доктор, профессор отдела антропологической археологии Кильский университет имени Кристиана Альбрехта (2. Киль, Федеративная Республика Германия)

Аннотащия. Древнее городище Амня I - уникальный памятник раннего неолита в таежной зоне Западной Сибири (Ханты-Мансийский автономный округ - Югра, река Амня). Он расположен на мысе и имеет три линии обороны и десять жилых впадин. Конструкция раскопанных жилищ идентична, хотя совокупность артефактов выглядит неоднородной. Нами был проведен технико-технологический анализ керамики, который показал отсутствие корреляции между формовочными массами, с одной стороны, и морфологией и орнаментацией посуды - с другой. Планиграфический анализ керамики показал, что сосуды с гребенчатыми и прочерченными узорами обнаружены в разных жилищах, хотя есть объекты, в которых обе группы залегают совместно. Различные категории каменного инвентаря (микропластинки и шлифованные наконечники стрел) также тяготеют к разным частям памятника. Скорее всего, наблюдаемые различия в вещевом комплексе объектов связаны с этапами функционирования городища. Радиоуглеродная хронология не устанавливает последовательности возведения и существования жилищ и оборонительных сооружений. Новая дата AMS не совпадает с радиоуглеродными датами, полученными ранее. Вероятно, она удревнена за счет значительного резервуарного эффекта. Обилие нерешенных вопросов абсолютной и относительной хронологии делает актуальным возобновление исследований на данном памятнике.

Ключевые слова: Западная Сибирь; Нижнее Приобье; таежная зона; ранний неолит; городище; керамика; каменный инвентарь; жилищные комплексы; радиоуглеродное датирование; планиграфический анализ; технико-технологический анализ керамики; технико-морфологический анализ каменного инвентаря.

\section{Введение}

Появление в таежной зоне Западной Сибири ранненеолитических поселений со сложной структурой является уникальным феноменом и требует пристального изучения [1]. Одним из таких ярких памятников является городище Амня I. Памятник расположен в Белоярском районе ХМАО-Югры на правом берегу р. Амня (приток р. Казым) и состоит из двух площадок на мысу боровой террасы. Оно имеет три линии обороны, вероятно, последовательно сменявшие одна другую. Каждая состоит изо рва и примыкающей к нему валообразной насыпи, в основании которой прослежена канавка от частокола (рис. 1). На двух площадках городища расположены 8 жилищных впадин, еще две находились за пределами укреплений [2-4]. Городище Амня I является ключевым в изучении раннего неолита таежной зоны Западной Сибири в целом и амнинского культурного 